\title{
RELATIONSHIP BETWEEN SUSTAINABLE DEVELOPMENT AND GREEN ECONOMY - EMPHASIS ON GREEN FINANCE AND BANKING $^{1}$
}

\author{
Olja Munitlak-Ivanovic ${ }^{2}$,Jovan Zubovic ${ }^{3}$, Petar Mitic ${ }^{4}$
}

\begin{abstract}
Summary
In this paper authors review the issue of relationship between economy, society and environmental protection. This could not be done without the three sustainability principles being incorporated in the concept of sustainable development and later in the concept of green economy. Many definitions of both concepts refer to the fact that these relationships are complex, as economic well-being and environmental protection cannot "reconcile" in the short run. The aim of green economy is to even economy, society and environment. Green finance was developed within this new economic concept. One instrument of green finance, i.e. socially responsible finance is the Equator principles. This thesis shows the mechanism of action of financial institutions which accepted these new principles, but also points out disadvantages that must be removed over time so that these principles could have a positive impact on society and environment.
\end{abstract}

Key words: Concept of sustainable development, Green economy, socially responsible behaviour, environment, the Equator principles

JEL: $Q 01, Q 56$

\section{Introduction}

Chronologically speaking, the concept of sustainable development appeared before the concept of green economy. Sustainable development began to be observed as a necessary behaviour

1 This paper is a part of research projects numbers III47009 (European integrations and social and economic changes in Serbian economy on the way to the EU) and OI179015 (Challenges and prospects of structural changes in Serbia: Strategic directions for economic development and harmonization with EU requirements), financed by the Ministry of Education, Science and Technological Development of the Republic of Serbia.

2 Olja Munitlak-Ivanović Ph.D., Senior Research Associate, Institute of Economic Sciences, Zmaj Jovina Street no. 12, 11000 Belgrade, Serbia, Phone: + 381112622 357, E-mail: olja.ivanovic@ien.bg.ac.rs

3 Jovan Zubović Ph.D, Senior Research Associate, Institute of Economic Sciences, Zmaj Jovina Street no. 12, 11000 Belgrade, Serbia, Phone: +381 112623 055,E-mail: jovan.zubovic@,ien.bg.ac.rs

4 Petar Mitić M.A., Research Assistant, Institute of Economic Sciences, Zmaj Jovina Street no. 12, 11000 Belgrade, Serbia, Phone: + 381112622 357, E-mail: petar.mitic@ien.bg.ac.rs

EP 2017 (64) 4 (1467-1482) 
in the second half of the twentieth century, when ecological disasters became more and more intense and the awareness of the need for environmental protection increased. Green economy as a concept appeared at the beginning of the twenty-first century, partly as a consequence of unsatisfactory results of implementing the concept of sustainable development.

Many definitions of sustainable development refer to various opinions of what this concept should include and with how many pillars it should be supported. The end of the twentieth century is characterized by intense environmental disasters which, as a result, increase environmental pollution. Rapid population growth at a global level, followed by intense technical and technological processes, resulted in growing needs of non-renewable energy, raw materials and other natural resources. These problems first appeared in the countries with the highest population growth rate, i.e. in the countries whose development was sudden and rapid. Speaking of this occurrence, we primarily refer to China and India, which means that it had partly local character. However, this trend was transferred to the global level due to this rapid economic development (Munitlak Ivanović et al., 2014).

The aim of creation and implementation of sustainable development is to establish an adequate relationship between production growth (economic aspect), extraction of natural resources (ecological aspect) and life conditions (social aspect). Giving a choice based on the principle ,economy versus ecology“ is not sustainable. "It can be concluded that sustainable development is in joint action with economic growth (economic efficiency and productivity growth, technology modernization etc.), social progress (socially responsible business with poverty alleviation, public health improvement etc.) and environment (reduction of pollution, biodiversity preservation etc.)“(Stanojević et al., 2013).

Chart of the above described relationship is shown below:

Figure 1. Interrelationship between economic, ecological and social aspect in the concept of sustainable development

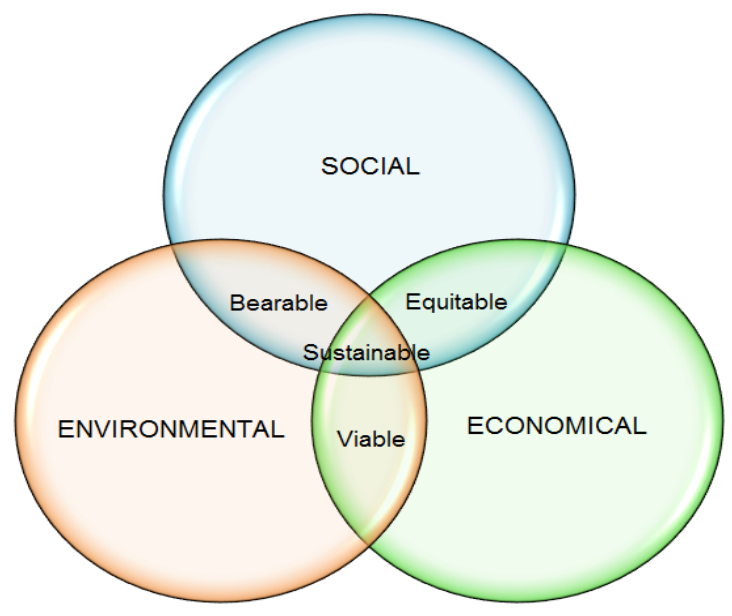

Source: United Nations Forum on Sustainability Standards (2017), (available at: https://unfss.org/workareas/topics/additional-areas/) 
There are many definitions of green economy although essentially they don't differ very much. The term itself indicates an eco-friendly principle, involvement of green technology in such economy and production, importance of environmental protection and socially responsible behaviour of not only individuals and companies, but also socially responsible behaviour at a global level (Ilić Petković, 2015). Such a preference is quite clear, taking into consideration that environmental disasters do not know territorial and geopolitical boundaries and divisions. They are regional and global and they have a growth trend.

The attempts of the society to prepare for these and other unexpected shocks and bring the balance of all pillars of society back are reflected in a new concept - resilience (OECD, 2014). Unlike the concept of sustainable development, the concept of resilience is based on four pillars due to its nature - its aim is to prevent shocks and make the society more flexible. Namely, pillars of resilience and sustainable development are similar, but the essential novelty in the concept of resilience is that it is based on four pillars. A new, fourth pillar is the pillar referring to institutional flexibility (Munitlak Ivanović, Mitić, 2016).

\section{Literature Review}

One can say that sustainable development appeared as a concept in 1980 as the first environmental protection strategy that was developed with a basic task: "sustainable development through protection of natural resources". This strategy was created by the International Union for Conversation of Nature and Natural Resources and it was explained and criticized by Lele (1991).

Sustainable development was officially defined and accepted as a concept, that is, as a possible model of development in 1987 at the $42^{\text {th }}$ session of the General Assembly of the United Nations. The World Commission on Environment and Development defined sustainable development in the report entitled "Our Common Future" as "a development which satisfies present needs without threatening the possibilities of future generations to satisfy their needs" (Brundtland, 1987). The Commission itself was formed earlier, in 1983, at the $38^{\text {th }}$ session of the General Assembly of the United Nations. If development is regarded as the increase in welfare, sustainable development means that this welfare is not reduced over time.

The above mentioned definition of sustainable development is the most popular and most accepted, but it is not the only one. This definition is politically acceptable and the concept of sustainable development defined in this way was widely accepted very soon. However, "sustainable development is not included in any discipline as a whole, but it is included in many scientific disciplines: economy, technology, ecology, law, sociology, ethics..." (Munitlak Ivanović, 2007) indicating its multidisciplinary nature.

Green economy, like sustainable development, does not have a common definition which is generally accepted (Vladisavljević et al., 2017). Since there is no consensus on the definition of green economy, the attitude of each country determines the role and significance of green economy according to its needs and its own vision. Therefore, the concept of green economy is defined according to the vision that has been generally accepted in the each countries' economic theory. The basic goal of green economy is to ensure economic growth followed by the growth of

EP 2017 (64) 4 (1467-1482) 
employment, where knowledge plays a pivotal role as it is one of the main sources of long-term economic growth (Tomić, 2015) and salaries with timely prevention of environmental disasters. Logical sequence of unadjusted economic and ecological pillar of sustainability is a situation in which the growth of production and consumption has negative impacts on the environment: increased noise level, environmental pollution, extraction of natural resources, especially fossil fuels, and other production and consumption inputs. Therefore, the goal of green economy is to ensure sustainable production and consumption, as extraction of natural resources in order to increase production growth cannot go on forever (Kalyta, 2016).

According to some theoreticians, green economy contains all achievements of the concept of sustainable development - these achievements being extended by efforts to increase total human wellbeing, reduce social inequality and number and volume of environmental disasters (Szabo, 2016).

In order to talk about green finance as a manifestation and implementation of concepts of sustainable development and green economy, its close relationship with socially responsible behaviour and business should be pointed out.

Socially responsible business is a concept. Ebner and Baumgartner (2006) researched a relationship between sustainable development and socially responsible business. The results of this research indicate that no definition defines exactly the relationship between sustainable development and socially responsible business. The same research has shown that socially responsible business and sustainable development are equated in practice within the cluster of financial institutions. Essentially, such an attitude speaks of considering sustainable development as a phenomenon which is observed at the macro level, while the concept of socially responsible business is considered as a manifestation of sustainable development at the micro level. The relationships observed in this way indicate the attitude that the concept of sustainable development is a basis of socially responsible business (Ebner, Baumgartner, 2006). Rana et al. (2009) came to the same conclusion. In his thesis, Dahlsrud (2008) analyses various definitions of socially responsible business and confirms the attitude that there is no common definition of socially responsible business, indicating at the same time that five basic dimensions always appear in observations and definitions of various theoreticians: interest groups, economic aspects, environmental protection and social environment, followed by goodwill for such business. Dahlsrud perceives that, in early definitions of socially responsible business, the role of environmental protection is small, but it grows into a significant characteristic over time, when distinction is made between exclusively profit-oriented and socially responsible business (Dahlsrud, 2008).

\section{Relationship between Sustainable Development and Green Economy}

Technical, technological and economic researches in this field should be oriented to environmental protection in order to analyse the impact and anticipate consequences of irresponsible behaviour in production. There are many reasons for this: soil degradation, climate changes, GHG emissions and any other activity that can threaten the future or even survival at the global level (Golušin et al., 2012).

It has already been pointed out that green economy and sustainable development cannot be 
equated. In the relationships set in this way sustainable development is an instrument for implementation of green economy (Ilić Petković, A., 2015, Pokrajac, S., 2009, Unković, Kordić, 2012). Certainly, there are similarities between these two concepts as all ecological activities being undertaken contribute to implementation of both concepts at the same time. In this way, sustainable development really is a basis of realization of green economy (Unković, Kordić, 2012). If production and/or consumption have any negative effects or cause extraction of non-renewable resources, sustainable development does not exist. This means that the concept of green economy is implemented not only when economy accepts "green" business principles, but also when social dimension is taken into consideration, that is, when all forms of social equalization are taken into account (Popović et al., 2015). The above mentioned facts indicate that natural resources, especially non-renewable resources, have limits of exploitation. On the contrary, if resources are exploited irresponsibly and without a plan, production and society will collapse sooner or later due to lack of resources and this is contrary to the bases of the concept of sustainable development and green economy. If relationships are set in this way, these two concepts are equal and absolutely harmonized (Munitlak Ivanović, 2007).

\section{Relationship between Sustainable Development, Socially Responsible Business and Green Economy}

The concept and idea of socially responsible business was published for the first time in 1889 in an article "The Gospel of Wealth" written by Andrew Carnegie. Carnegie is the first author who publicly claims that a company must help and therefore improve the quality of the society and environment in which it operates. However, his attitude was not accepted then (Cooper, 2000). Great depression and the collapse of financial market in the 1930s resulted in reassessment of this attitude, but no significant improvements were noticed until the 1950s. This was a result of devastations after the World War Two, as well as of establishing new international and economic relationships. However, the role of the country and its activity related to workers and society was considered for the first time.

At the beginning, owners of capital were afraid that undertaking of such activities would have negative impact, and that it will result in reduction of corporate profit. In the 1970s, when multinational companies appeared, more responsible behaviour towards workers and environment started to be implemented as a result of a pressure on companies to develop such concept of business. Due to numerous industrial, especially environmental disasters whose consequences were felt globally, such way of doing business became significant and started to be implemented in practice more intensely. Essentially, socially responsible activities, according to Sredojević, finally start to be implemented in the 1990s. In that sense, Sredojević (2006) points out: ,Activities of many companies had negative impacts on environment and therefore multinational companies had to adopt codices of corporate behaviour. Until then, the activities were voluntary, which was the cause of ecological, ethnical and financial scandals of that time, as well as of scepticism in terms of globalization of multinational companies and their business responsibility, transparency in business and commitment to social development and welfare." 
Figure 2: Pyramid of corporate social responsibility

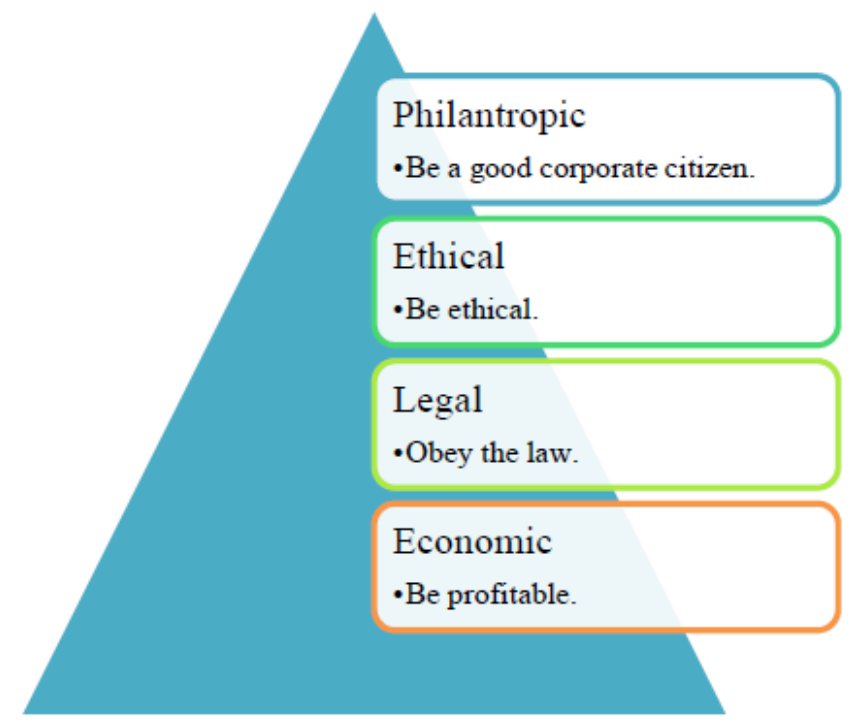

Source: (Sredojević, 2006) taken from: Carroll (1991): The Pyramid of Social Responsibility: Toward the Moral Management of Organizational Stakeholders.

The most realistic model of socially responsible business has a pyramid-like shape and it indicates clear interaction of determinants consisting of: philanthropic, ethical, legal and economic factors. The model was developed by Carrol in 1991. Philanthropic factor is at the top of the pyramid and Carrol identified it as the most important factor which is in mandatory synergy with ethical, legal and economic factor. The model was tested in theoretical researches and in practice and it proved to be applicable and optimal as an instrument of assessment of managerial behaviour in successful companies.

Terms "socially responsible business"; "corporate social responsibility"; "social responsibility of companies" or "corporate responsibility" are, in fact, synonyms for the behaviour Carrol described as philanthropically, ethically, legally and economically justified and simultaneous. Likewise other new social approaches, these synonyms will acquire status of scientific discipline over time.

As in green economy and sustainable development, there is no common definition of socially responsible behaviour. Various authors and international institutions have different approaches, but various forms of protection are in the essence of all scientific determinations of this term: consumers' interest, environment, workers' rights, interest of business partners and competitors, corporate protection and common protection of global society.

Authors of this paper opted for definitions of two international institutions, the World Bank and European Commission. The World Bank defines socially responsible behaviour as: "Commitment and contribution of profit sector to sustainable development through work with employees, their families, local communities and society as a whole in order to improve quality of life through the process that benefits a company and contributes to general 
development" (Petkoski, Twose, 2003). The European Commission's definition is shorter and more simple - it determines this concept as "corporate responsibility for their impact on society" (European Commission, 2011).

However, from the point of view of the owners of capital, the impact of socially responsible business on corporate profit is a very important issue. There is no common opinion in this field as well, but it can be noticed that there are three principles used. Chapple et al. (2005) and Herbohn (2005), express a dose of "fear", i.e. an attitude that socially responsible business results in increased corporate costs. Other authors have completely different approach to this issue and they think that socially responsible business is not a cost, but an investment in human capital of the company (Chamorro, Bangail, 2006, Klein, Dawar, 2004). The third approach could be called neutral. Authors Wang \& Bansal (2012) and Carter (2005) are of the opinion that there is an impact of socially responsible business on companies and operations, but this impact varies and has different consequences. Essentially, relationship "social responsibility versus profit" includes duality "economy versus ecology", i.e. "longterm sustainability versus green economy”.

\section{Green Banking and the Role of the Equator Principles in Green Economy}

The term "green banking" itself indicates close relationship with business principles which are characteristic for green economy and therefore it is surely a part of socially responsible business (Munitlak Ivanović et al., 2015). This global trend was initiated by international institutions such as Group 20 (G20), International Finance Corporation-IFC as a member of the World Bank, World Trade Organization-WTO, and United Nations-UN. Nongovernmental organizations have a special role in implementation of this form of financing.

In order to be considered to comprise elements of green banking, a form of financing has to contain two elements: environmental protection and social protection. To realize such business method of profit-sensitive financial institutions, it was necessary to start various forms of international initiatives, i.e. programmes. From the standpoint of these programmes and initiatives, social protection and/or environmental protection can have binding character (they are created at the national level) or non-binding character (they are created by nongovernmental organizations and therefore they can have either international or branch character).

Creation and especially implementation of any change is not a simple process, particularly if it does not contain profit growth in itself directly (Munitlak Ivanović, 2015). This characterizes the beginning of development of green banking in 1992 at the United Nations Framework Convention on Climate Change (UNFCCC). This first attempt directed observation on the relationship between profit (as a return on invested capital) and climate changes which have negative impacts on the environment and society and therefore on instability of profits. The first concrete agreement is the Kyoto protocol, with various mechanisms, of which Clean Development Mechanism (Munitlak Ivanović, Bagarić, 2006), i.e. "cap and trade“" system (Munitlak Ivanović et al. 2014) is most significant. Although a stock market for trading GHG emissions was formed, this agreement did not give good results in practice, as countries which 
emitted most harmful gases from production did not ratify or apply it. (Golušin, Munitlak Ivanović, 2011).

After partly successful implementation of this mechanism, a new agreement was signed in Copenhagen. The aim of this agreement was to increase liabilities of developed countries to 100 billion dollars per year in order to reduce GHG emissions. Due to failure of this agreement in practice, a new agreement was signed in Cancun, confirming the necessity for operationalization of liabilities from Copenhagen and amount of these liabilities. Speaking of implementation of these obligations in practice, countries find various ways to avoid implementation of this obligation. The latest agreement, signed in Paris in 2015, is partly optimistic. Disadvantage of this document is a time of its coming into force, which will start when 55 countries (out of 195 member states in total) which emit about $55 \%$ of GHG gases ratify it.

The above mentioned protocols and mechanisms mainly deal with issues of environmental protection. In addition to these, there are new ones whose aim is simultaneous social and environmental protection, which will be achieved by creating of ISO standards 26000 , Global Reporting Initiative (GRI), "Global Agreement" and other similar agreements and mechanisms. There are also other initiatives, the most famous being the United Nations Environment Programme Finance Initiative (UNEP FI), Institutional Investors Group on Climate Change (IIGCC), United Nations Principles for Responsible Investment (UN PRI), Equator principles and other initiatives, forums and associations. The question is how financial institutions which are primarily motivated by interest and profit can have an effect on improvement of society and environment. Each of the above mentioned initiatives has a specific way of functioning. Due to limited volume of this paper, authors have chosen the Equator principles.

The Equator principles are a form of risk assessment, determination and management in project financing. Their goal is protection against risks related to social and environmental management at the same time (The Equator Principles Association, 2011). The Association's vision is to determine minimum standards for risk assessment of both society and environment in order to minimize negative impact of approved funds. The Equator Principles Association was established as a result of the desire of a certain number of financial institutions to raise their socially responsible behaviour to as high level as possible (The Equator Principles Association, 2011).

The headquarters of the Equator Principles Association Secretariat is in London. Board of directors consists of 12 members, some of which are establishers of the Association and others come from the presiding bank. The work of the Association is based on standards prescribed and applied by the International Finance Corporation-IFC. The review of the Equator principles III is given in Table 1. The Equator principles started to be applied in 35 countries in 84 financial institutions. In this way, the risk of project financing related to society and environment is minimized. Until now, the percent of coverage of such financing is over $70 \%$. 
Table 1: Review of Equator principles III

\begin{tabular}{|c|c|}
\hline Theme & THE EQUATOR PRINCIPLES III \\
\hline Scope & $\begin{array}{ll}- & \text { Project Finance } \\
- & \text { Project Finance Advisory } \\
- & \text { Project-Related-Corporate Loans } \\
\text { - } & \text { Bridge Loans }\end{array}$ \\
\hline $\begin{array}{l}\text { EP Association Member } \\
\text { Public Reporting }\end{array}$ & $\begin{array}{l}\text { Minimum requirements: } \\
\text { - } \quad \text { Number of "Projects Closed" including: categorization, sector, region } \\
\text { and whether an independent review has taken place } \\
\text { - } \quad \text { Project Names for Project Finance deals (subject to client consent) } \\
\text { - } \quad \text { Info on EP implementation process including roles and } \\
\text { responsibilities, staffing, policies and procedures } \\
\text { - } \quad \text { Details on training mandatory for first year of EP adoption. }\end{array}$ \\
\hline Client Public Reporting & $\begin{array}{l}\text { - Online summary of Environmental and Social Impact Assessment. } \\
\text { Greenhouse Gas (GHG) emission levels for projects emitting over } \\
100,000 \text { tons of CO2 annually during operational phase. }\end{array}$ \\
\hline Social & 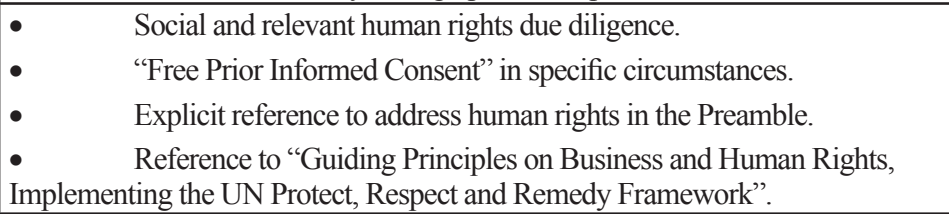 \\
\hline Climate & $\begin{array}{l}\text { - Attention in due diligence. } \\
\text { Alternative analysis for high emitting projects in line with } \\
\text { Performance Standard 3. } \\
\text { - } \quad \text { Explicit reference to address climate change in the Preamble. } \\
\text { Project reporting requirements on GHG emission levels: } \\
\text { - Mandatory: projects emitting }+100 \mathrm{~K} \text { tons of } \mathrm{CO} 2 . \\
\text { - Encouragement: projects emitting }+25 \mathrm{~K} \text { tons of } \mathrm{CO} 2 .\end{array}$ \\
\hline Language Alignment & Environmental and social risks and impacts. \\
\hline
\end{tabular}

Source: The Equator Principles III (2013)

Project financing is the first field in which the Equator principles have been introduced, as the impact of each project on society and environment is easiest to be followed. This supports the claim mentioned in the abstract that the Equator principles are the important part of green economy through green banking. According to their negative impact on the environment, loans are divided into categories A, B and C. Funds from category A, for example for construction of plants that use coal, have the biggest negative impact on the environment. On the contrary, a project financed with funds from category $\mathrm{C}$ has small or no negative impact on the environment. Because of this, independent auditors' reports containing impact assessment on the environment have to be submitted together with projects that are financed with funds from category $\mathrm{A}$ and $\mathrm{B}$, in order to determine other methods of production later which will reduce these negative impacts.

The client that takes funds is obliged to implement the Equator principles in the project by means of an agreement in which the client's responsibilities related to protection are clearly 
defined. Realization of responsibilities undertaken according to this agreement is followed in the Action plan, which can be a part of the agreement or annexed to it. If the central bank or some legislative authority prescribed these responsibilities, there is no need for this agreement.

Principles can be defined as methods and techniques of impact assessment of approved funds on the environment and society for the entire duration of the concrete project. The table below shows ten principles that are vital for the Equator principles mechanism. The impact of the client's approved funds on the environment and society is determined based on fulfilment/ non-fulfilment of these principles.

The Equator principles III (2013) are the following:

- Principle 1: Review and Categorization

- Principle 2: Environmental and Social Assessment

- Principle 3: Applicable Environmental and Social Standards

- Principle 4: Environmental and Social Management System and Equator Principles Action Plan

- Principle 5: Stakeholder Engagement

- Principle 6: Grievance Mechanism

- Principle 7: Independent Review

- Principle 8: Covenants

- Principle 9: Independent Monitoring and Reporting

- Principle 10: Reporting and Transparency

Since the introduction of first Equator principles in 2003 two audits were performed, in 2006 and 2013. The above classification is in accordance with the latest audit from 2013. Audits were performed under the significant influence of non-governmental sector and motives for these audits were the following (UNEP, 2016):

1. Deficiencies in the first report published by the Equator Principles Association and stakeholders

2. Modification of standards within the International Finance Corporation-IFC

3. Necessity for more simple implementation and more detailed definition of standards.

The following deficiencies were listed in the study conducted by the United Nations Environment Programme (UNEP, 2016):

1. Majority of financial institutions which introduced the Equator principles use this mechanism mainly for creating of positive public image or as a basis for establishing of the risk assessment system - as risk management.

2. Absence of financial incentives, such as special interests (bonuses) for users of 
these funds, is mentioned as a methodological deficiency. Essentially, this means that there is no mechanism of financial incentive for users of these funds which really invest funds in a manner that does not endanger the environment or society. Or shortly, there is no reward system for financiers of socially responsible projects.

3. A significant deficiency is the existence of obligation to indicate projects that emit more than 100.000 tons of CO2 in the report, while there is no mechanism that could stop financing of such projects or demand an adequate substitution.

4. Due to lack of information, reports make impact analysis of financed projects on the environment and society impossible.

\section{Conclusion}

Responsible and conscious societies build long-term national sustainable development strategies. Essentially, this is green economy. In this paper it is pointed out that there is no common understanding of the concept of green economy, but that definitions of almost all authors indicate five identical elements: stakeholders and economic aspects of their profit, environmental protection and social matters followed by goodwill of socially responsible business.

The paper mentions dilemmas on the relationship between sustainable development and green economy. The authors' attitude is that sustainable development is "older" since it appeared earlier as a concept and therefore its implementation started earlier. A series of national and later even local strategies was developed based on a number of international documents with the aim of incorporating pillars of sustainability in continuous social and environmental protection. These processes were incorporated easily in some economies and hardly in other. Green economy as a concept appeared later and its aim was to facilitate, fasten and implement principles of sustainable development in practice. The task of green economy, as a part, system, sub-system or any other form of mutual conditionality with the concept of sustainable development, is to start global changes in terms of poverty reduction and improvement of human well-being with constant economic growth. As a function of socially responsible business, green economy results in boosting of business based on sustainability principles both at macro and micro level. Technological innovations should result in reduction of production costs, not in the growth of these costs. Otherwise, better choice would be ecologically cleaner, but economically less acceptable (uncompetitive) production.

Although there is no common definition of green economy and each country defines it according to its own needs and visions, it is clear that these two concepts are inextricably linked and conditioned. In practice, a process or procedure will not be acceptable from the point of postulates of green economy if one or more principles of sustainable development are not complied with at the same time. On the other hand, it is certain that such business is completely safe and socially responsible. 
Likewise two previous concepts, there is no common and official definition of socially responsible business, but each definition contains philanthropic, ethical, legal and economical factor. A pyramid-like model was developed in 1991. Various observations developed by international institutions and some authors have been mentioned in this paper and it can be noticed that all definitions insist on various forms of protection (consumers' interest, environment, workers' rights, interest of business partners and competitors, corporate protection, i.e. protection of global society).

What is interesting is a phenomenon of green banking and social responsibility in financial institutions. Banks have always been focused on profit and, if possible, on profit growth trends. However, as a result of intense development of green economy, the principle of sustainability and social responsibility extended to financing as well. This resulted in development of climate finance and other forms of green finance.

Creation of the Equator principles and participation of financial institutions in this process speaks of raising awareness in this field. The idea of the Equator Principles Association is to determine minimum required standards that a project has to meet in order to get funds from financial institutions which accepted these principles. The basic idea is to finance projects having minimum negative impacts on the society and environment from these funds.

Likewise any mechanism, the Equator principles have their methodological deficiencies, but they certainly represent a step towards green economy and sustainable development.

\section{Literature}

1. Brundtland, G. H. (1987): Report of the World Commission on environment and development: "Our Common Future", United Nations.

2. Carnegie, A., (june 1889): The Gospel of Wealth, The Pall Mall Gazette, London, United Kingdom.

3. Carroll, A. B. (1991): The pyramid of corporate social responsibility: Toward the moral management of organizational stakeholders. Business horizons, vol. 34, no. 4, pp. 39-48, Elsevier Inc., United States, (DOI: 10.1016/0007-6813(91)90005-G).

4. Carter, C. R. (2005): Purchasing social responsibility and firm performance: The key mediating roles of organizational learning and supplier performance. International Journal of Physical Distribution \& Logistics Management, vol. 35, no. 3, pp. 177-194, Emerald Group Publishing Limited, United Kingdom, (DOI: 10.1108/09600030510594567).

5. Chamorro, A., Bañegil, T. M. (2006): Green marketing philosophy: a study of Spanish firms with ecolabels. Corporate Social Responsibility and Environmental Management, vol 13, no. 1, pp. 11-24, Wiley-Blackwell, United Kingdom, (DOI: 10.1002/csr.083). 
6. Chapple, W., Paul, C. J. M., Harris, R. (2005): Manufacturing and corporate environmental responsibility: cost implications of voluntary waste minimisation. Structural Change and Economic Dynamics, vol. 16, no. 3, pp. 347-373, Elsevier BV, Netherlands, (DOI: 10.1016/j.strueco.2004.04.003)

7. Cooper, S. (2000): Shareholder Wealth or Societal Welfare: A Stakeholder Perspective/Arnold G. Value Based Management. Context and Application. New York, Wiley\&Sons Ltd.

8. Dahlsrud, A. (2008): How corporate social responsibility is defined: an analysis of 37 definitions, Corporate social responsibility and environmental management, vol. 15, no.1, pp. 1-13, John Wiley \& Sons, Inc., United Kingdom, (DOI: 10.1002/ csr.132).

9. Ebner, D., Baumgartner, J. R. (2006): The relationship between Sustainable Development and Corporate Social Responsibility, Corporate Responsibility Research Conference. Dublin, Ireland. (available at: http://www.crrconference.org/ Previous conferences/downloads/2006ebnerbaumgartner.pdf)

10. European Commission, (25.10.2011): Communication from the Commission to the European Economic and Social Committee and the Committee of the regions: A renewed EU strategy 2011-2014 for Corporate Social Responsibility, Brussels: European Commission.

11.Golušin, M., Munitlak Ivanović, O., (2011): Kyoto Protocol implementation in Serbia as precognition of sustainable energetic and economic development, Energy Policy, vol. 39, no. 2, pp. 2800-2807, Elsevier BV, United Kingdom, (DOI: 10.1016/j. enpol.2011.02.052)

12. Golušin, M., Munitlak Ivanovic, O., Jovanovic, L., Domazet, S. (2012): Determination of ecological-economic degree of development in Countries of SE Europe - weight coefficients technique, Problemy ekorozwoju, vol. vii, no.1., pp. 87-93. European Academy of Science and Arts, Salzburg, Austria.

13. Herbohn, K. (2005): A full cost environmental accounting experiment. Accounting, Organizations and Society, vol. 30, no. 6, pp. 519-536, Elsevier Ltd. (DOI: 10.1016/j.aos.2005.01.001).

14. Ilić Petković, A. (2015): Sustainable development and green economy similarities and differences, Ecologica, no. 79, pp. 561-563, Naučno-stručno društvo za zaštitu životne sredine Srbije "ECOLOGICA", Beograd, Srbija.

15. Kalyta, P. (2016): SMEs Achievement of exellent quality - Basic requirements for Green Economy, Final Workshop Report on „SMEs and Green Economy“, Organization of the Black Sea Economic Cooperation (BSEC) and KonradAdenauer-Stiftung (KAS), Kyiv, Ukraine, pp. 276-283.

16. Klein, J., Dawar, N. (2004): Corporate social responsibility and consumers' attributions and brand evaluations in a product - harm crisis. International Journal of research in Marketing, vol. 21, no. 3, pp. 203-217. Elsevier BV, Netherlands, (DOI: 10.1016/j.ijresmar.2003.12.003). 
17. Lele, S. M. (1991): Sustainable development: a critical review, World development, vol. 19, no. 6, pp. 607-621, Elsevier, United Kingdom, (DOI: 10.1016/0305-750X(91)90197-P).

18. Munitlak Ivanović O., Mitić, P., Raspopović, N. (2015): Klimatske finansije - instrument globalne klimatske politike, Ecologica, vol. 22, no. 79, pp. 541-545, Naučno-stručno društvo za zaštitu životne sredine Srbije „ECOLOGICA“, Beograd, Srbija

19. Munitlak Ivanović, O. (2007): Održivi razvoj kao redefinisan pristup ekonomskom razvoju, Zadužbina Andrejević, Beograd, Srbija.

20. Munitlak Ivanović, O. (2015): Osetljivost privrede na klimatske promene, Međunarodna naučna konferencija: Životna sredina i adaptacija na klimatske promene, Beograd, Srbija, pp. 19-20.

21. Munitlak Ivanović, O., Bagarić, I. (2006): Implementacija održivog razvoja delovanjem međunarodnog ekonomskog instrumenta-Mehanizmi Kjoto protokola, Četvrta regionalna konferencija o uzajamnosti zaštite životne sredine i efikasnosti energetskih sistema, Elektra IV.

22. Munitlak Ivanović, O., Mitić, P. (2016): A theoretical investigation of Sustainable development and Resilience, Impact of Economic Policies on Attaining Resilieng Growth, Belgrade, Serbia, pp. 67-69.

23. Munitlak Ivanović, O., Raspopović N., Mitić P., Jovanović L. (2014): Novi pristupi i načini merenja bogatstva u održivoj privredi, Ecologica - Međunarodna naučna konferencija: Održiva privreda i životna sredina, Beograd, Srbija, pp. 15-17.

24. Munitlak Ivanović, O., Raspopović, N., Mitić, P. (2014): Specifični oblici međunarodne trgovine „Cap and Trade“ sistem, Poslovna ekonomija, vol. 15, no. 2, pp. 115-126, Fakultet za uslužni biznis, Sremska Kamenica, Srbija.

25. OECD (2014): Overview Paper on Resilient Economies and Societies, Meeting of the OECD Council at Ministerial Level, Paris, May 2014, (available at: https:// www.oecd.org/mcm/C-MIN(2014)7-ENG.pdf).

26. Petkoski, D., Twose, N. (2003): Public policy for corporate social responsibility. WBI Series on Corporate Responsibility, (available at: http://web.worldbank.org/ archive/website01006/WEB/IMAGES/PUBLICPO.PDF)

27. Pokrajac, S. (2009): Održivi razvoj i ekološka ekonomija kao poslovne paradigme, Škola biznisa, vol xx, no. iv, pp. 21-30, Visoka poslovna škola strukovnih studija Novi Sad, Srbija.

28. Popović, S., Munitlak Ivanović, O., Jovanović, L. (2015): Zelena ekonomija kao faktor razvoja privrede Srbije i prerada manje opasnog otpada, Ecologica, vol. xxii, no. 80, pp. 693-697, Naučno-stručno društvo za zaštitu životne sredine Srbije "ECOLOGICA", Beograd, Srbija. 
29. Rana, P., Platts, J., Gregory, M. (2009): Exploration of corporate social responsibility (CSR) in multinational companies within the food industry, CRR Conference, United Kingdom, (available at: http://www.crrconference.org/ Previous conferences/downloads/rana.pdf)

30. Sredojević, S. (2006): Društvena odgovornost korporacije - Corporate social responsibility (CSR), Bankarstvo, vol 7, no. 8, Udruženje banaka, Beograd, Srbija, (available at: http://www.ubs-asb.com/Portals/0/Casopis/2006/7 8/UBSBankarstvo-7-8-2006-Sredojevic.pdf).

31. Stanojević, D., Mitić, P., Rakić, S. (2013): Strategija bankarskog sektora u kontekstu održivog razvoja - perspektive Srbije, XVIII Internacionalni naučni skup SM2013 - Strategijski menadžment i sistemi podrške odlučivanju u strategijskom menadžmentu "Korporativno upravljanje u funkciji održivog razvoja", Subotica, Srbija, pp. 437-446.

32. Szabo, A. (2016): Eco- innovation and Green Action plan for SMEs in the European Union, Final Workshop Report on "SMEs and Green Economy“, Organization of the Black Sea Economic Cooperation (BSEC) and KonradAdenauer-Stiftung (KAS), Kyiv, Ukraine, pp 27-40.

33. The Equator Principles Association (2011): (availabe at: http://www.equatorprinciples.com).

34. The Equator Principles III (2013): (available at: http://www.equator-principles. com/resources/equator_principles_III.pdf)

35. Tomić, Z. (2015): Analysis of the Impact of Public Education Expenditure on Economic Growth of European Union and BRICS, Economic Analysis, vol. 48, no. 2015/1-2, pp. 19-38, Institute of Economic Sciences, Belgrade, Serbia, (available at: http://www.ien.bg.ac.rs/images/stories/Izdavastvo/Economic\%20 analysis/2015/2015 1-22.pdf).

36. UNEP (2016): (available at: http://web.unep.org/).

37. United Nations Forum on Sustainability Standards (2017), (available at: https:// unfss.org/work-areas/topics/additional-areas/).

38. Unković, M., Kordić, N. (2012): Održivi razvoj i ekologija, X naučni skup Sinergija, Bijeljina, Bosna i Hercegovina, pp. 11-21.

39. Vladisavljević, V., Knežević, M., Jovanović, D. (2017): Uslovi i mogućnosti ostvarivanja održivog razvoja, VII Međunarodni kongres Revizija, Palić, pp. 183194.

40. Wang, T., Bansal, P. (2012): Social responsibility in new ventures: profiting from a long-term orientation. Strategic Management Journal, vol. 33, no. 10, pp. 1135-1153, John Wiley \& Sons Ltd., United Kingdom, (DOI: 10.1002/smj.1962). 


\title{
ODNOS ODRŽIVOG RAZVOJA I ZELENE EKONOMIJE - OSVRT NA ZELENE FINANSIJE I BANKARSTVO
}

\author{
Olja Munitlak-Ivanovic ${ }^{5}$,Jovan Zubović ${ }^{6}$, Petar Mitic ${ }^{7}$
}

\section{Rezime}

U radu autori razmatraju pitanje odnosa između privrede, društva i zaštite životne sredine. To nije moguće uraditi bez tri principa održivosti koji moraju biti uključeni u konceptu održivog razvoja, a kasnije i u koncept zelene ekonomije. Veliki broj definicija oba koncepta ukazuju na činjenicu da su ovi odnosi kompleksni, s obzirom da se ekonomsko blagostanje $i$ zaštita životne sredine ne mogu da "pomiriti" u kratkom roku. Cilj zelene ekonomije je da izjednače ekonomske, društvene $i$ životne aspekte. Zelene finansije su razvijene u ovom novom konceptu. Jedan instrument zelenih finansija, pa i društveno odgovorne finansije su Ekvatorski principi. Ovaj rad pokazuje mehanizme delovanja finansijskih institucija koje su prihvatile nove principe, ali takođe ističe i nedostatke koji se moraju ukloniti tokom vremena, tako da ovi principi mogu imati pozitivan uticaj na društvo i životnu sredinu.

Ključne reči: održivi razvoj, zelena ekonomija, društveno odgovorno poslovanje, životna sredina, Ekvatorski principi

5 Dr Olja Munitlak-Ivanović, Viši naučni saradnik, Institut ekonomskih nauka, Zmaj Jovina Ulica br. 12, 11000 Beograd, Srbija, Telefon: + 381112622 357, E-mail: olja.ivanovic@,ien.bg.ac.rs

6 Dr Jovan Zubović, Viši naučni saradnik, Institut ekonomskih nauka, Zmaj Jovina Ulica br. 12, 11000 Beograd, Srbija, Telefon: +381 112623 055, E-mail: jovan.zubovic@ien.bg.ac.rs

7 Petar Mitić M.A., Istraživač saradnik, Institut ekonomskih nauka, Zmaj Jovina Ulica br. 12, 11000 Beograd, Srbija, Telefon: + 381112622 357, E-mail: petar.mitic@ien.bg.ac.rs 
ECONOMICS OF

AGRICULTURE

\section{CONTENT}

1. Adriana Radosavac, Desimir Knežević

ECONOMIC IMPORTANCE OF USE

OF PESTICIDES IN WHEAT PRODUCTION . . . . . . . . . . . 1323

2. Berhe Gebregewergs, Muuz Hadush

DOES CLIMATE CHANGE AFFECT PRICE OF VEGETABLES:

EVIDENCE FROM TIGRAI, NORTHERN MOST ETHIOPIA. . . . .1335

3. Grujica Vico, Aleksandra Govedarica-Lučić, Zoran Rajić, Radomir Bodiroga, Ivan Mičić, Silvija Zec Sambol, Marija Mičić

MULTI ATTRIBUTE ASSESSMENT APPROACH

IN VEGETABLE PRODUCTION . . . . . . . . . . . . . . 1355

4. Igor Trandafilović, Vesna Conić, Aleksandra Blagojević

IMPACT OF DEMOGRAPHIC FACTORS ON

ENVIRONMENTALLY CONSCIOUS PURCHASE BEHAVIOUR. . .1365

5. Imre Milán Harcsa

STUDY ON THE POTENTIAL OF SUBCONTRACT

PALINKA DISTILLATION . . . . . . . . . . . . . . 1379

6. Jelena Andrašić, Vera Mirović, Nada Milenković, Branimir Kalaš, Miloš Pjanić

IMPACT OF TAKEOVER PROCESS ON EMPLOYEES -

EVIDENCE FROM FOOD, RETAIL AND FINANCIAL SECTOR . . .1393

7. Jelena Birovljev, Danilo Đokić, Bojan Matkovski, Žana Kleut

ECONOMIC PERFORMANCES OF AGRICULTURE

OF CEFTA AND FORMER CEFTA COUNTRIES . . . . . . . . . . 1413

8. Jelena Marković, Svetlana Stevović

SUSTAINABILITY OF CHEMICAL SOIL QUALITY

IN SOUTHERN MORAVA RIVER VALLEY

IN CORELLATION WITH THE FLOODING $\ldots \ldots \ldots \ldots \ldots$ 
9. Mile Peševski, Zoran Milovančević

THE CHANGES IN THE USAGE OF AGRICULTURAL LAND

IN EASTERN REGION OF REPUBLIC OF MACEDONIA

BETWEEN $1991-2030 \ldots \ldots$. . . . . . . . . . . . . . . . . . . . . . .

10. Odjuvwuederhie Emmanuel Inoni, 'Oraye Dicta Ogisi, Felix Odemero Achoja

PROFITABILITY AND TECHNICAL EFFICIENCY IN HOMESTEAD

CATFISH PRODUCTION IN DELTA STATE, NIGERIA . . . . . . . 1449

11. Olja Munitlak - Ivanović, Jovan Zubović, Petar Mitić

RELATIONSHIP BETWEEN SUSTAINABLE DEVELOPMENT AND

GREEN ECONOMY - EMPHASIS ON GREEN FINANCE

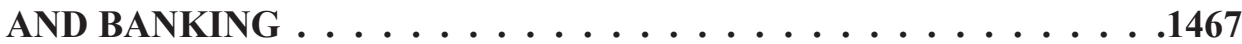

12. Petar Munćan, Dragica Božić

FARM SIZE AS A FACTOR OF EMLOYMENT AND INCOME

OF MEMBERS OF FAMILY FARMS . . . . . . . . . . . . . 1483

13. Rade Popović, Mira Kovljenić

EFFICIENCY OF WHEAT PRODUCTION ON FARMS

IN THE REPUBLIC OF SERBIA . . . . . . . . . . . . . . . . . . . . . . . . .

14. Radovan Damnjanović, Snežana Krstić, Milena Knežević, Svetislav Stanković,

Dejan Jeremić

THE DISCRIMINANT ANALYSIS APPLIED TO THE

DIFFERENTIATION OF SOIL TYPES . . . . . . . . . . . . 1513

15. Slavica Otović, Dunja Demirović, Kristina Košić, Aleksandra Vujko

FOSTERING ENTERPRENUERSHIP AT HIGH SCHOOLS:

A CASE OF RURAL AREAS IN VOJVODINA (SERBIA) . . . . . . .1523

16. Vladimir Ilić, Ivan Bauer, Anastazija Tanja Đelić, Aleksandar Nešković

INSTITUTIONAL SUPPORT FOR STRENGTHENING

ENTREPRENEURSHIP IN AGRICULTURAL PRODUCTION

OF THE REPUBLIC OF SERBIA . . . . . . . . . . . . . . . . . . . . . . . .

17. Boro Krstić, Zorica Vasiljević, Miroslav Nedeljković

INSURANCE CONTRACT AS THE BASIS FOR THE SAFETY OF

AGRICULTURAL PRODUCERS IN THE REPUBLIC OF SRPSKA • . 1555

18. Dejan Sekulić, Aleksandar Petrović, Vladimir Dimitrijević

WHO ARE WINE TOURISTS? AN EMPIRICAL INVESTIGATION

OF SEGMENTS IN SERBIAN WINE TOURISM . . . . . . . . . . . . . 
19. Milan Beslać, Ćorić Goran

FINANCIAL AND PRODUCTION ASPECTS OF GENETICALLY MODIFIED ORGANISMS $\ldots \ldots \ldots \ldots \ldots \ldots \ldots \ldots \ldots$

20. Mlađan Maksimović, Darjan Karabašević, Miodrag Brzaković, Pavle Brzaković THE EFFECTS RESULTING FROM THE APPLICATION OF THE CONCEPT OF THE SUSTAINABLE DEVELOPMENT OF RURAL TOURISM ON STARA PLANINA . . . . . . . . . . . . . . . .1595

21. Vesna Popović, Predrag Vuković, Milivoje Ćosić FOOD SAFETY AND QUALITY POLICY IN THE REPUBLIC OF SERBIA . . . . . . . . . . . . . . . . 1607

22. Radovan Pejanović, Danica Glavaš-Trbić, Mirela Tomaš-Simin PROBLEMS OF AGRICULTURAL AND RURAL DEVELOPMENT IN SERBIA AND NECESSITY OF NEW AGRICULTURAL POLICY . . . .1619

23. Saša Marković, Slavoljub Vujović, Aleksandar Damnjanović MARKETING AND HIGHER EDUCATION CONDITION IN SERBIA . . . . . . . . . . . . . . . . 1635

24. Semir Vehapi, Marina Milanović THE EFFECT OF MARKET ORIENTATION ON BUSINESS PERFORMANCE OF SERBIAN ORGANIC PRODUCERS . . . . . 1651

25. Suad Bećirović, Šemsudin Plojović, Enis Ujkanović, Senadin Plojović CHALLENGES AT STARTING AN AGRIBUSINESS IN THE HILLY MOUNTAINOUS REGIONS OF SOUTHWEST SERBIA . . . . . . . .1669

26. Vladimir Zakić, Vlado Kovačević, Jelena Damnjanović SIGNIFICANCE OF FINACIAL LITERACY FOR THE AGRICULTURAL HOLDINGS IN SERBIA . . . . . . . . . . 1687

27. Željko Bjelajac, Marijana Dukić Mijatović, Željko Vojinović PROTECTION OF LAND IN THE REPUBLIC OF SERBIA AND ECOLOGICAL SECURITY WITH REGARD TO STRATEGIC AND LEGAL FRAMEWORKS . . . . . . . . . .1703 